\title{
Isolation and characterization of EPEC phage from domestic waste in Indonesia
}

\author{
Debi Arivo', Iman Rusmana ${ }^{2}$, Sri Budiarti ${ }^{1,2^{*}}$ \\ ${ }^{1}$ Reseach Center for Bioresources and Biotechnology, Bogor Agriculture University, Darmaga Campus, Bogor, 16680, \\ Indonesia. \\ ${ }^{2}$ Department of Biology, Faculty of Mathematics and Natural Sciences, Bogor Agricultural University, Darmaga Campus, \\ Bogor 16680, West Java, Indonesia. \\ Email: s_budiarti@yahoo.com
}

Received 7 May 2015; Received in revised form 2 October 2015; Accepted 7 October 2015

\begin{abstract}
Aims: Enteropathogenic Escherichia coli (EPEC) K1.1 is one of pathogenic bacteria-causing diarrheal disease. This bacterium was resistant to tetracycline and ampicillin. The use of lytic phage can be a good solution to reduce antibiotic resistance of pathogenic bacteria. This study was to isolate and characterize phage that can lyse EPEC K1.1 cells.

Methodology and results: Lytic phage was isolated from domestic waste at Darmaga, Bogor, West Java, Indonesia. It uses double layer plaque technique. The kind of phages was determined by the plaque morphology, the structure, the host range, and the protein characteristics of phages as well as storage stability of phage in different buffer conditions. Lytic phage only infects the EPEC K1.1. It does not infect the other bacteria in this research. Electron microscope observation showed that phage FBd3 has icosahedral head with $57.14 \mathrm{~nm}$ in diameter and short-non contractile tail with $18.2 \mathrm{~nm}$ in length. It was grouped into family Phodoviridae. Lytic phage had good storage stability in Ringers buffer at low temperature $\left(4^{\circ} \mathrm{C}\right)$. It showed that viability of phage decreased by $28.04 \%$ after 9 days of storage. Phage FBd3 has six different proteins with various molecular weight: $33 \mathrm{kDa}, 42 \mathrm{kDa}, 49 \mathrm{kDa}, 57 \mathrm{kDa}, 77 \mathrm{kDa}$ and 106.7 kDa. This study indicates that EPEC K1.1 can be infected by more than one type of lytic phages.

Conclusion, significance and impact of study: Lytic phage FBd3 reduces the population of PEC K1.1 effectively. It can be used as a bio-control agent to EPEC that contaminates food and water. Lytic phage found in this study potentially prevent bacterial contamination in food and beverage processing for diarrheal disease prevention.
\end{abstract}

Keywords: Lytic phage, EPEC, diarrhea

\section{INTRODUCTION}

Enteropathogenic Escherichia coli (EPEC) is one of foodborne disease bacteria which causes diarrheal disease transmitted by contaminated water and food (Miliotis and Bier, 2003; Newell et al., 2010; Osman et al., 2012). This bacterium attacks babies under five years old in a developing country for more than $50 \%$ cases of diarrheal disease in the world. A virulent factor of EPEC is due to their colonization on intestinal surface, and causes alternation of the intestine mucosal cells (Mearin et al., 2005). EPEC has extracellular proteolytic enzymes that can degrade mucin as a defensive system on human intestine (Budiarti and Mubarik, 2007). Antibiotics are commonly used to decrease exposure of pathogenic bacteria. However, the use of inappropriate antibiotics dose affects on bacterial resistance. This resistance was caused by mutations of bacterial chromosome or plasmid gene transferred from bacteria (Zhang et al., 2006).

The previous study reported that EPEC K1.1 isolated from diarrheal patient was resistant to tetracycline and ampicillin (Budiarti, 1998). Other studies reported that $E$. coli pathotypes causing diarrheal isolated from children in the age of six months to five years old in India more than $70 \%$ was resistant to norfloxacin, amoxicillin, cotrimoxazole, ampicillin, ceftriaxone, cefotaxime and metronidazole (Sudershan et al., 2014). Resistance on antibiotics is not only found in pathogenic bacteria, but also it is found in normal flora bacteria. It was reported that $E$. coli as intestinal normal flora isolated from feces of new born children was antibiotic-resistant (Budiarti, 2011).

Lytic phage can be a good solution to reduce antibiotic-resistant of pathogenic bacteria (Hagens and Loessner, 2010). Phage is specific and effective to lyse targeted bacteria without disturbing normal flora (Brovko et al., 2012). The advantage of using the phage its own ability to replicate if its host bacterium exists and it will be inactive if its host bacterium does not exist (Fu et al., 2010). The susceptibility of bacteria against phage infection is mostly related to the variation of receptor molecules, restriction modification system in host cells, or 
other phage tolerant systems such as abortive infection (Flynn et al., 2004).

Based on previous study, in Indonesia, some phages that lyse pathogenic bacteria has been isolated. Bacteriophage isolated from Ciapus River was infected to Bacillus pumilus isolated from sewage water (Kusmiatun et al., 2015). Photobacterium damselae infecting fish and human can be lysed by lytic phage isolated from environment (Novianti et al., 2014). An antibiotic-resistant bacterium called Proteus mirabilis isolated from feces of diarrheal patient can be lysed by lytic phage (Afriani et al., 2014). FB4 lytic phage can lyse $85 \%$ of EPEC K1.1 which is an antibiotic-resistant bacterium (Budiarti et al., 2011). The objective of this research was to isolate and characterize EPEC K1.1 phage to contribute in making phage cocktail as a bio-control agent.

\section{MATERIALS AND METHODS}

\section{Bacterial stock preparation}

EPEC K1.1 used in this study was an isolate bacterial collection at laboratory of Animal Biotechnology and Biomedicine, Bogor Agricultural University, Bogor, West Java, Indonesia. EPEC K1.1 isolate was grown on Eosine Methylene Blue Agar (Oxoid, Basingstoke, UK) plates showing good growth with metalic green sheen color. It was grown on Nutrient Agar medium (Difco, Becton Dickinson and Company, USA) as a bacterial stock.

\section{Lytic phage isolation}

Lytic phages were isolated from domestic waste at Darmaga, Bogor, West Java, Indonesia. About $1 \mathrm{~mL}$ of sample was diluted to $9 \mathrm{~mL}$ Nutrient Broth (Difco, Becton Dickinson and Company, USA) and centrifuged at $4000 \mathrm{~g}$ for $30 \mathrm{~min}$. Supernatant was filtered using $0.45 \mu \mathrm{m}$ pore size syringe filter. About $4.5 \mathrm{~mL}$ of filtrate was added to 0.5 $\mathrm{mL}$ of exponential phase culture $\left(10^{9} \mathrm{CFU} / \mathrm{mL}\right)$ of EPEC $\mathrm{K} 1.1$. The sample was incubated overnight at $37^{\circ} \mathrm{C}$. The culture was centrifuged at $4000 \mathrm{~g}$ for $30 \mathrm{~min}$. Supernatant was filtered using $0.22 \mu \mathrm{m}$ pore size syringe filter and was saved in sterile tube at low temperature (Atterbury et al., 2007). Plaque assay was done using double layer plaque technique by adding $100 \mu \mathrm{L}$ of filtrate to $100 \mu \mathrm{L}$ exponential phase culture of EPEC K1.1 and incubated it at $37^{\circ} \mathrm{C}$ for $30 \mathrm{~min}$. The culture was added into $7 \mathrm{~mL}$ at 47 ${ }^{\circ} \mathrm{C}$ soft agar and poured it into Nutrient Agar medium. The plates were incubated at $37^{\circ} \mathrm{C}$ for $24 \mathrm{~h}$. Plaque formation was observed and counted (Clokie and Kropinski, 2009).

\section{Phage morphology determination}

Morphology of phages was determined using Transmission Electron Microscope (TEM) at Eijkman Institute. About 10 $\mu \mathrm{L}$ of each phage isolate of was dropped on grid (400 mesh) and left for $30 \mathrm{sec}$. About $5 \mu \mathrm{L}$ of $2 \%$ Uranyl acetate was dripped on grid and dried using a filter paper. The grids were observed using JEM-1010 transmission electron microscope (JEOL, Tokyo, Japan) at magnification of 10,000-100,000× (Carey et al., 2006).

\section{Determination of phage host range}

Lytic phage suspension was tested to several bacterial strains i.e EPEC K1.1, Salmonella P38, Salmonella P84, Proteus mirabilis, $B$. pumilus, and $P$. damselae. Host range test was conducted using double layer plaque technique (Atterbury et al., 2007). A positive response was indicated by the formation of plaques.

\section{Stability of Iytic activity in buffer storage}

Ringers buffer $\left[8 \mathrm{~g} \mathrm{NaCl}, 0.42 \mathrm{~g} \mathrm{KCL}, 0.24 \mathrm{~g} \mathrm{CaCl}_{2}, 0.20 \mathrm{~g}\right.$ $\mathrm{NaHCO}_{3}$ in $1 \mathrm{~L} \mathrm{H}_{2} \mathrm{O}$ ], and Saline Magnesium (SM) buffer [5.8 g NaCl, $2 \mathrm{~g} \mathrm{MgSO}_{4} \cdot 7 \mathrm{H}_{2} \mathrm{O}, 50 \mathrm{~mL}$ Tris-Cl (pH 7.5), 5 $\mathrm{mL}$ gelatine in $1 \mathrm{~L} \mathrm{H}_{2} \mathrm{O}$ ] were used as buffers for storing phage. Nutrient broth was used as a control. Two Petri dishes of phage plaque isolates were scraped and diluted in buffer. Each of suspensions was mixed thoroughly using a vortex for $30 \mathrm{sec}$ and left at room temperature for an hour. Centrifugation was done at $4000 \mathrm{~g}$ and $4{ }^{\circ} \mathrm{C}$ for 20 min. Supernatant was filtered by $0.22 \mu \mathrm{m}$ pore size syringe filter and the supernatant was stored at $4{ }^{\circ} \mathrm{C}$ and $27^{\circ} \mathrm{C}$. Viability of phage was determined by plating it using double layer plaque technique every three days (Phumkhachorn and Rattanachaikunsopon, 2010).

\section{Analysis of phage protein}

Proteins of phage were analysed by SDS-PAGE (Laemmli, 1970). The marker was a pre-stained protein (Pageruler Prestained Protein Ladder, Thermo Scientific Fermentas Technology, UK). Phage proteins were mixed with marker in buffers with ratio of $4: 1$ and incubated for $24 \mathrm{~h}$. The mixtures were boiled for $5 \mathrm{~min}$. The phage and sample markers were put in loading wells of $60 \mu \mathrm{L}$ SDS-PAGE gel containing $12 \%$ of acrylamide. The electrophoresis was conducted at $20 \mathrm{~mA}, 50$ Volt for $3.5 \mathrm{~h}$. After the electrophoresis, the gel was removed from the glass plates and then silver staining was applied to visualize the result.

\section{RESULTS}

\section{Lytic phage isolates}

Host bacterium for lytic phage isolation has been confirmed as EPEC K1.1. It showed metalic green sheen bacterial colony on EMBA (Figure 1). Four phage isolates i.e. FBd1, FBd2, FBd3 and FBd4 have been isolated. They showed different morphology of plaque (Figure 2) and different concentration of phage: FBd1 $\left(2.8 \times 10^{3}\right.$ $\mathrm{PFU} / \mathrm{mL}), \mathrm{FBd} 2\left(1.1 \times 10^{4} \mathrm{PFU} / \mathrm{mL}\right), \mathrm{FBd} 3\left(3.4 \times 10^{6}\right.$ $\mathrm{PFU} / \mathrm{mL})$ and FBd4 $\left(6 \times 10^{2} \mathrm{PFU} / \mathrm{mL}\right)($ Table 1$)$. From the plaque forming unit, data showed that FBd3 had the highest concentration indicating the effective phage to lyse EPEC K1.1. 


\section{Host range of phage FBd3}

There are six strains of bacteria EPEC K1.1. that have been tested as bacterial hosts of phage FBd3: Salmonella P38, Salmonella P84, $P$. mirabilis, B. pumilus, and $P$. damselae. Each of bacteria mixed with phage $\mathrm{FBd} 3$ using double layer plaque technique and incubated at $37^{\circ} \mathrm{C}$ for $24 \mathrm{~h}$. The result showed clear zones only appeared on EPEC K1.1 was infected by phage FBd3 on overlay agar (Table 2), while Salmonella P38, Salmonella P84, $P$. mirabilis, $B$. pumilus, and $P$. damselae in this research was not infected by phage FBd3.

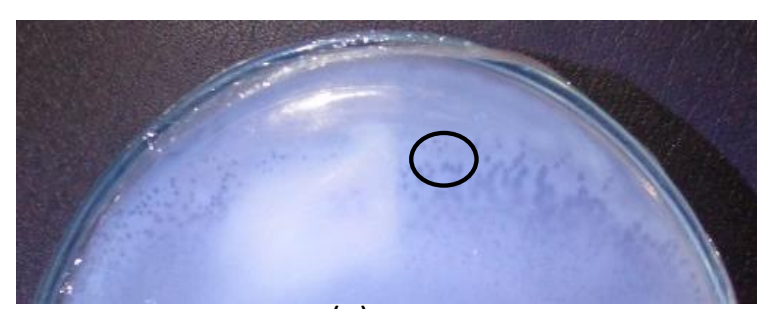

(a)

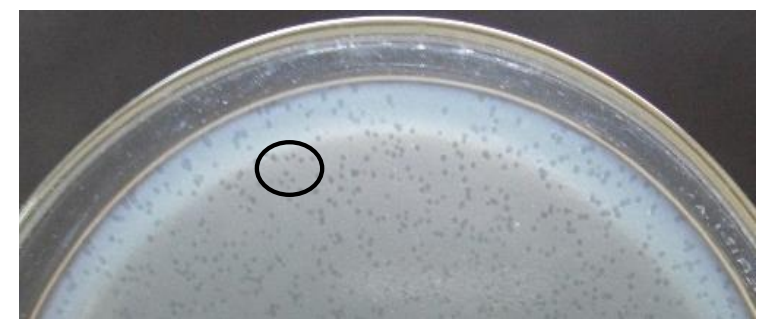

(c)

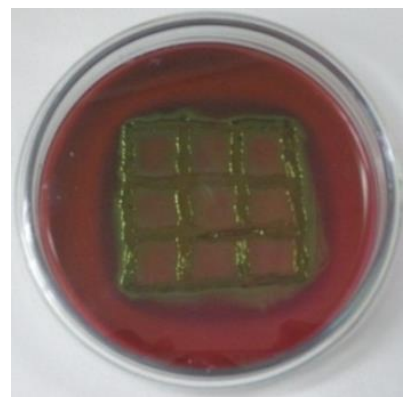

Figure 1: EPEC K1.1 on Eosine Methylene Blue Agar (EMBA).
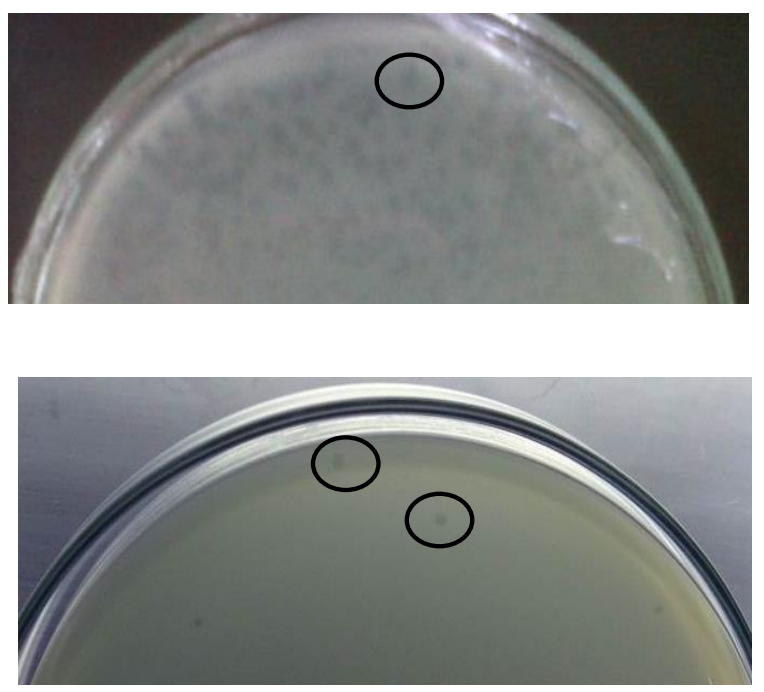

(d)

Figure 2: Plaque morphology of EPEC K1.1 lytic phages isolated from domestic waste in Indonesia. (a) Lytic phage FBd1; (b) lytic phage FBd2; (c) lytic phage FBd3 and (d) lytic phage FBd4.

Table 1: Plaque characteristics and concentration of EPEC K1.1 lytic phages.

\begin{tabular}{ccccc}
\hline Sample location & $\begin{array}{c}\text { Lytic phage } \\
\text { isolate }\end{array}$ & \multicolumn{2}{c}{ Characteristics of plaque } & \multirow{2}{*}{$\begin{array}{c}\text { Titer } \\
(\mathrm{PFU} / \mathrm{mL})\end{array}$} \\
\cline { 3 - 4 } & & Plaque morphology & $\begin{array}{c}\text { Diameter of plaque } \\
(\mathrm{mm})\end{array}$ & $0.2 ; 0.7$ \\
\hline Babakan Raya1 & FBd1; FBd2 & Clear; turbid & 0.5 & $2.8 \times 10^{3} ; 1.1 \times 10^{4}$ \\
Babakan Raya & FBd3 & Clear & - & $3.4 \times 10^{6}$ \\
Babakan Raya3 & - & - & 0.3 & - \\
Jl.Darmaga & FBd4 & Clear & - & $6 \times 10^{2}$ \\
Ciapus River & - & - & & - \\
\hline
\end{tabular}

Table 2: Host range of phage FBd3.

\begin{tabular}{lcc}
\hline & Bacteria strains & Plaque formation \\
\hline EPEC K1.1 & + \\
Salmonella P38 & - \\
Salmonella P84 & - \\
Proteus mirabilis & - & - \\
Bacillus pumilus & - \\
Photobacterium damselae & - \\
\hline
\end{tabular}




\section{Phage morphology}

Based on Transmission Electron Microscope micrograph (with 80,000× magnification), phage FBd3 has icosahedral head with $57.14 \mathrm{~nm}$ in diameter and short non-contractile tail with $33.3 \mathrm{~nm}$ in length (Figure 3). Based on its characteristic and according to International Committee on Taxonomy of Viruses database (ICTVdB, 2000), phage FBd3 can be grouped into Phodoviridae.

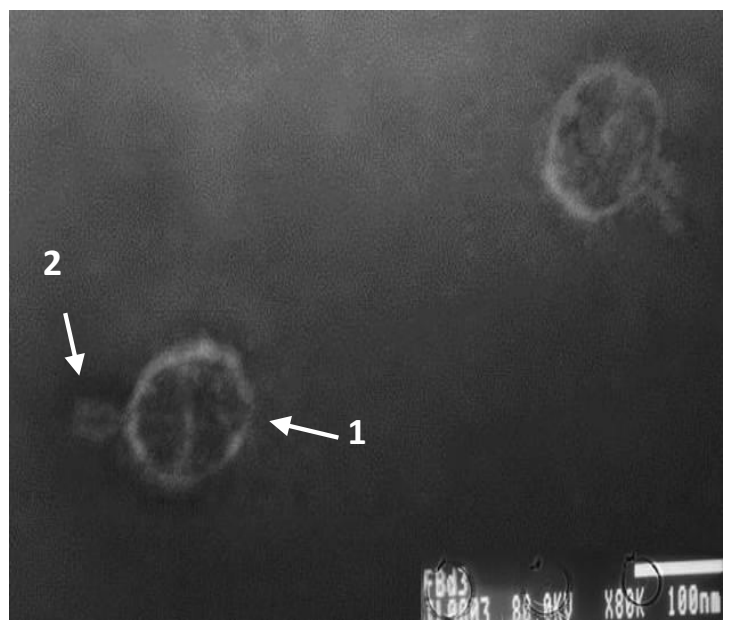

Figure 3: Transmission Electron Microscope micrograph of lytic phage FBd3 with $80,000 \times$ magnification. (1) Head of phage, and (2) Tail of phage.

\section{Stability of phage in buffer storage}

Phage FBd3 has good storage stabillity in Ringers buffer at low temperature $\left(4^{\circ} \mathrm{C}\right)$. Its viability decreased by $28.04 \%$ after 9 days of storage. If it was stored at $27^{\circ} \mathrm{C}$, the viability decreased by $7.18 \%$ after 9 days of storage. However, if the phage was stored in SM buffer at low $\left(4^{\circ} \mathrm{C}\right)$ and room temperature $\left(27^{\circ} \mathrm{C}\right)$, the viability decreased by $40.18 \%$ and $58.5 \%$ respectively. The control treatment stored in NB showed that the viability decreased by $94.7 \%$ at low temperature, moreover it was no viable phage when it was stored in NB at room temperature after 9 days of storage (Figure 4).

\section{Phage protein characteristics}

Protein analysis using SDS-PAGE showed that phage FBd3 had seven protein bands with different size of molecular weight. Based on the protein marker, the molecular weight of phage $\mathrm{FBd} 3$ proteins were 33 $\mathrm{kDa}, 42 \mathrm{kDa}, 49 \mathrm{kDa}, 57 \mathrm{kDa}, 77 \mathrm{kDa}$, and $106.7 \mathrm{kDa}$ (Figure 5).

\section{DISCUSSION}

Clear zone (plaque) on plate indicated the area of lysed bacteria which could be a parameter as a result of lytic phage infection to host bacterium (Carter and Saunders, 2007). Each of the phage isolate has different characteristics as well as their ability to lyse bacterial cells. Plaques morphology of

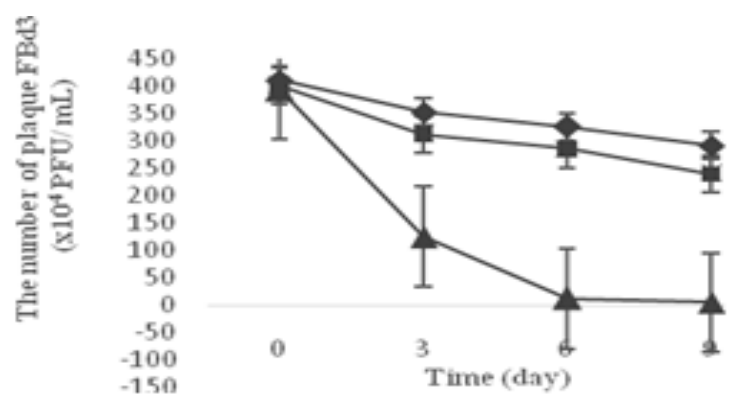

(a)

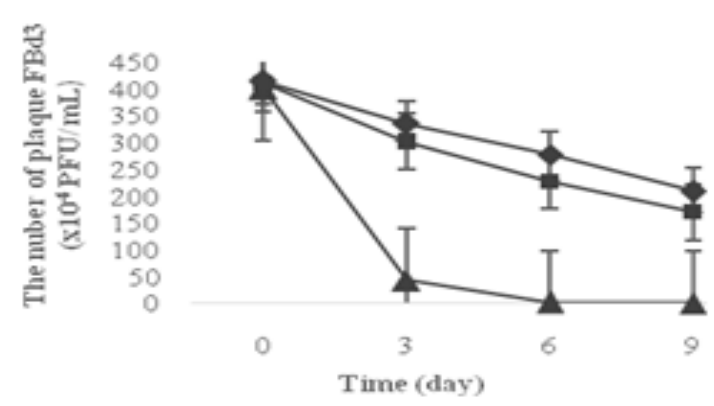

(b)

$\mathbf{F i}$

gure 4: Storage stability of phage FBd3 in various buffers. (a) storage at low temperature, and (b) storage at room temperature. $\$$ : Ringers buffer, a: SM buffer, $\boldsymbol{\Delta}$ : Nutrient Broth. Bars indicate standard deviations.

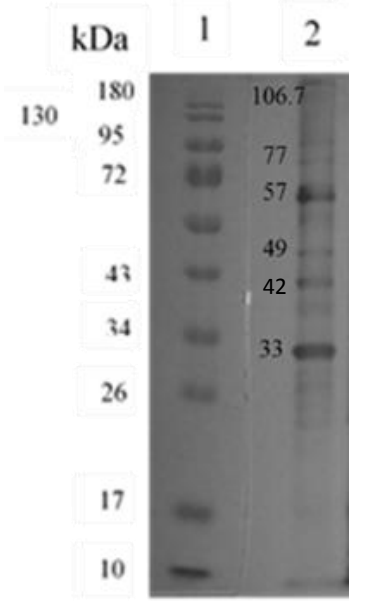

Figure 5: SDS-PAGE results of phage FBd3 proteins. (1) protein marker, and (2) proteins of phage FBd3.

phage $\mathrm{FBd} 1, \mathrm{FBd} 2, \mathrm{FBd} 3$, and $\mathrm{FBd} 4$ was $0.2 \mathrm{~mm}$ in diameter with clear plaque, $0.7 \mathrm{~mm}$ in diameter with turbid plaque, $0.5 \mathrm{~mm}$ in diameter with clear plaque, and $0.3 \mathrm{~mm}$ in diameter with clear plaque, respectively. Phage FBd3 can lyse more bacterial cells of EPEC K1.1.than the other phage isolates. Phage can lyse host cells because of its ability in synthesizing lysozyme in the bacterial cells. Lysozyme was synthesized by phage for damaging bacterial cell wall by cutting $\beta-1,4-$ glycosidic bond between $\mathrm{N}$-acetyl glucosamine and $\mathrm{N}$-acetyl muramic acid of peptidoglycan (Madigan et al., 2009). It causes the lysis of bacterial cells and newly formed phages are released (Tortora et al., 2006). 
There are several factors that can affect plaque formation. Rapidity to lyse bacterial cells is one factor that can determine plaque morphology and size. This factor can make different appearing of plaque either in morphology or in size (Gallet et al., 2011). Rapidity of plaque formation was related to rapidity of phage multiplication (Pelczar and Chan, 2007). Phage FBd3 was infected EPEC K1.1. They can lyse bacterial cells of EPEC K1.1. from plaque forming unit, phage FBd3 showed the highest concentration of phage (Table 1). FB4 infecting EPEC K1.1 has phage concentration of $1.6 \times 10^{4} \mathrm{PFU} / \mathrm{mL}$ (Budiarti et al., 2011). It means that phage FBd3 is different from phage FB4. So FBd3 can be applied as a bio-control agent of EPEC in contaminated water and food for diarrheal disease prevention.

Each phage has different receptors which determine its ability in infecting bacteria. The kinds of receptor specify the host range in phage infection (Bielke et al., 2007). Each phage recognizes different receptors on bacterial cell surface (Braunt and Hantke, 1997). Kinds of phage receptors are pili (Roncero et al., 1990), capsule (Suthereland et al., 2004), teichoic acid (Raisanen et al., 2007), lipopolysaccharide (Lindberg et al., 1978), and surface protein (Davison et al., 2005). Determination of host range (Table 2) showed that FBd3 was only lysed by EPEC K1.1 cells. It showed that among the tested bacteria in this study, the receptors of EPEC K1.1. may differ from others. This association is influenced by the specificity of receptor characteristic of each host. Phages identify their host bacterium by binding or adsorbing it to a specific structure on the surface of cells called as receptor. The basic of adsorption an interaction between specific structure on the surface of phage and a specific structure on the surface of bacterium (Kudva et al., 1999).

Transmission Electron Microscope micrographs proved that phage $\mathrm{FBd} 3$ has icosahedral head with $57.14 \mathrm{~nm}$ in diameter and short non-contractile tail with $33.3 \mathrm{~nm}$ in length (Figure 3). Based on its characteristic and according to International Committee on Taxonomy of Viruses (ICTV), phage FBd3 can be grouped into family Phodoviridae. However, there is a previous study reported that lytic phage FB4 infecting EPEC K1.1 having hexagonal icosahedral head with $81.56 \mathrm{~nm}$ in width and 103.11 $\mathrm{nm}$ in length was grouped into family Siphoviridae (Budiarti et al., 2011). It proved that EPEC K1.1 can be infected from different family of phage.

Several physical and chemical factors including temperature and ion determine viability of phage in environment. The inappropriate phage storage will cause a damage on tail, head, and DNA of phages (Jonczyk et al., 2011). Phage FBd3 had good storage stabillity in Ringers buffer at low temperature $\left(4^{\circ} \mathrm{C}\right)$ compared with SM buffers and nutrient broth. The composition of chemical compounds affects storage ability of lytic phage at different temperature in different buffer. The composition of $\mathrm{Ca}^{2+}$ and $\mathrm{Mg}^{2+}$ containing in ringers buffer could increase efficiency of phage adsorption in host cells (Cele, 2009). Denaturation and oxidation of phage proteins can be inhibited by storing the phage at low temperature which is needed to maintain the viability of phage protein (Fennema, 2008).
Proteins of phage capsid and tail are varied in size and functions which it depends on type of phages. Phage FBd3 has six different proteins with various molecular weight: $33 \mathrm{kDa}, 42 \mathrm{kDa}, 49 \mathrm{kDa}, 57 \mathrm{kDa}$, $77 \mathrm{kDa}$ and $106.7 \mathrm{kDa}$ (Figure 5). The variety of protein molecular weight indicates the variety of its protein function. Protein of phage with molecular weight of $33 \mathrm{kDa}$ and $42 \mathrm{kDa}$ allegedly are capsid forming protein. This is similar to Conway's study (1995) who isolated phage protein that infects EPEC with capsid protein constituent ranges between 33 $\mathrm{kDa}-42 \mathrm{kDa}$. Proteins of phage FBd3 is larger in size than that of lytic phage FB4 which also infects EPEC $\mathrm{K} 1.1$. Lytic phage FB4 has proteins with molecular weight in the range of $35.9-40.3 \mathrm{kDa}$ (Budiarti et al., 2011). This result indicated that EPEC K1.1 can be infected by more than one type of lytic phages. Therefore there is a high possibility that phage cocktail can lyse bacterial cells of EPEC K1.1 more effective than single phage. Some of previous studies reported that the effectiveness of phage applications in fighting against pathogenic bacteria depends on several factors, such as the phages/targeted bacteria ratio, the model and moment of treatment, environmental conditions, the neutralization and accessibility of phage to targeted bacteria (Ly-Chatain, 2014). A phage cocktail is more effective than single phage in order to kill bacteria (Schmerer et al., 2014; Bourdin et al., 2014).

\section{CONCLUSION}

Four lytic phages i.e. phage FBd1, FBd2, FBd3, and $\mathrm{FBd} 4$ were successfully isolated from domestic waste in Indonesia. The FBd3 phage, which has the widest diameter plaques compared to three other phages can lyse EPEC K1.1. Phage has showed its best viability when it is stored at low temperature $\left(4^{\circ} \mathrm{C}\right)$ in Ringers buffer. Phage $\mathrm{FBd} 3$ has six different proteins with various molecular weights: $33 \mathrm{kDa}, 42 \mathrm{kDa}, 49 \mathrm{kDa}$, $57 \mathrm{kDa}, 77 \mathrm{kDa}$ and $106.7 \mathrm{kDa}$.

\section{ACKNOWLEDGEMENT}

This study was supported by Directorate General of Higher Education, Ministry of National Education, Indonesia and Education Fund Management Institute, Ministry of National Finance, Indonesia. We thank Ms. Rizdika Mardiana for preparing this manuscript

\section{REFERENCES}

Afriani, R., Rusmana, I. and Budiarti, S. (2014). Characterization of Proteus mirabilis lytic phage from Situ Letik River Bogor Indonesia. International Journal of Innovative Research in Science and Engineering 2, 2347-3207.

Atterbury, R. J., Van Bergen, M. A. P., Ortiz, F., Lovell, M. A., Harris, J., De Boer, A., Wagenaar, J. A., Allen, V. M. and Barrow, P. A. (2007). Bacteriophage therapy to reduce Salmonella colonization of broiler chicken. Applied and Environmental Microbiology 73, 4543-4549.

Bielke, L., Higgins, S., Donoghue, A., Donoghue, D. and Hargis, B. M. (2007). Salmonella host range of bacteriophages that infect multiple genera. Poultry Science 86, 2536-2540. 
Braunt, V. and Hantke, K. (1997). Bacterial receptors for phages and colicins as constituents of specific transport systems. Microbial Interaction 3, 99-137.

Bourdin, G., Navarro, A., Sarker, S. A., Pittet, A. C., Qadri, F., Sultana, S., Cravioto, A., Talukder, K. A., Reuteler G. and Brüssow, H. (2014). Coverage of diarrhoea-associated Escherichia coli isolates from different origins with two types of phage cocktails. Microbial Biotechnology 7, 165176.

Brovko, L. Y., Anany, H. and Griffiths, M. W. (2012). Bacteriophages for detection and control of bacterial pathogens in food and food-processing environment. Advances in Food and Nutrition Research 67, 241-287.

Budiarti, S. (2011). Antibiotic resistance Escherichia coli isolated from faecal of healthy human. Journal of International Environmental Application and Sciences 6, 359-364.

Budiarti, S. and Mubarik, N. R. (2007). Extracellular protease activity of enteropathogenic Escherichia coli on mucin substrate. HAYATI Journal 14, 3638.

Budiarti, S., Pratiwi, R. H. and Rusmana, I. (2011). Infectivity of lytic phage to enteropathogenic Escherichia coli from diarrheal patients in Indonesia. Journal of Universal College of Medical Sciences 8, 72-81.

Budiarti, S. (1998). Telaah faktor adhesivitas Escherichia coli enteropatogenik dalam penanggulangan penyakit diare di Indonesia. Laporan Penelitian Hibah Bersaing III. Jakarta. Perguruan Tinggi DIKTI.

Carey, G., Billingtonv, C., Cornelius, A., Hudson, J. and Heinemann, J. (2006). Isolation and characterization of bacteriophages infecting Salmonella spp. FEMS Microbiology Letters 258, 182-186.

Carter, J. and Saunders, V. (2007). Virology: Principles and application. Wiley, United States. pp. 1-382.

Cele, N. (2009). Strategies to control bacteriophage infection in threonin bioprocess. M.Sc. Thesis. Durban University of Technology, South Africa.

Clokie, M. R. J. and Kropinsky, A. M. (2009). Bacteriophages methods and protocols. Humana Press, United Kingdom. pp. 69.

Conway, J. F., Duda, R. L., Cheng, N., Hendrix, R. W. and Steven, A. C. (1995). Proteolytic and conformational control of virus capsid maturation: The bacteriophage HK97. Journal of Molecular Biology 253, 86-99.

Davison, S., Couture-Tosi, E., Candela, T., Mock, M. and Fouet, A. (2005). Identification of the Bacillus anthracis y phage receptor. Journal of Bacteriology 187, 6742-6749.

Fennema, O. R. (2008).Fennema's food chemistry. CRC Press, USA. pp. 1-14.

Flynn, G. O., Ross, R. P., Fitzgerald, G. F. and Coffey, A. (2004). Evaluation of a cocktail of three bacteriophages for biocontrol of Escherichia coli O157:H7. Applied and Environmental Microbiology 3417-3424.

Fu, W., Forster, T., Mayer, O., Curtin, J. J., Lehman, S. M. and Donlan, R. M. (2010). Bacteriophage cocktail for the prevention of biofilm formation by Pseudomonas aeruginosa on catheters in an in vitro model system. Antimicrobial Agents and Chemotherapy 4, 397-404.

Gallet, R., Kannoly, S. and Ing, N. W. (2011). Effects of phage traits on plaque formation. BMC Microbiology 11, 181-185.

Hagens, S. and Loessner, M. J. (2010). Bacteriophage for biocontrol of foodborne pathogens: Calculations and considerations. Current Pharmaceutical Biotechnology 11, 58-68.

International Committee on Taxonomy of Viruses (ICTVdB). (2000). Index of viruses http://ictvdb.biomirror.cn/lctv/fs_podov.htm [Retrieved on 8 August 2014].

Jonczyk, E., Klak, M., Miedzybrodzky, R. and Gorski, A. (2011). The influence of external factors on bacteriophages. Folia Microbiologica 56, 191200.

Kudva, I. T., Jelacic, S., Tarr, P. I., Youderian, P., and Hovde, C. J. (1999). Biocontrol of Escherichia coli 0157 with O157-Specific Bacteriophages. Applied and Environmental Microbiology 65, 37673773.

Kusmiatun, A., Rusmana, I., Budiarti, S. (2015). Characterization of bachteriophage specific to Bacillus pumilus from Ciapus River, Bogor, West Java, Indonesia. HAYATI Journal 22, 27-33.

Laemmli, U. K. (1970). Cleavage of structure protein during the assembly of the head of bateriophage T4. Nature 227, 680-685.

Lindberg, A. A., Wollin, R., Gemski, P. and Wohlhieter, J. A. (1978). Interaction between bacteriophage Sf6 and Shigellaflexneri. Journal of Virology 27, 38-44.

Ly-Chatain, M. H.(2014). The factors affecting effectiveness of treatment in phages therapy. Frontiers in Microbiology 5, 1-7.

Madigan, M. T. and Brock, T. (2009). Biology of Microorganism. Pearson Prentice Hall, New Jersey. pp. 874

Mearin, F., Oliveras, M. P., Perello, A., Vinyet, J., Ibanez, A., Coderch, J. and Perona, M. (2005). Dyspepsia and Irritable Bowel Syndrome after a Salmonella gastroenteritis outbreak: One-year follow-up cohort study. Gastroenterology 129, 98104.

Miliotis, M. D. and Bier, J. W. (2003). International handbook of foodborne pathogens. M. Dekker. New York. pp. 743.

Newell, D. G., Koopmans, M., Verhoef, L., Duizer, E., Kane, A. A., Sprong, H., Opsteegh, M., Langelaar, M., Threfall, J., Scheutz, F., Giessen, J. V. D. and Kruse, H. (2010). Food-bornedisease the challenges of 20 years ago till persist while new ones continue to emerge. International Journal of Food Microbiology 139, 3-15.

Novianty, Rusmana, I. and Budiarti, S. (2014). Lytic bacteriophage for Photobacterium damselae isolated from water environment. International Journal of Innovative Reseach in Science and Engineering 2, 2347-3207.

Osman, M. M., Hassan, A. N. and Holie, M. A. (2012). Bacterial etiology of diarrhoeal diseases in children under 5 years old in Ombadda HospitalSudan. Sudanese Journal of Public Health 7, 9397.

Pelczar, M. J. and Chan, E. C. S. (2007). Dasardasar mikrobiologi 1. In: Microbiology. 
Hadioetomo, R. S., Imas, T., Tjitrosomo, S. S. and Angka, S. L. (eds.). UI Press, Jakarta. pp. 522.

Phumkhachorn, P. and Rattanachaikunsopon, P. (2010). Isolation and partial characterization of a bacteriophage infecting the shrimp pathogen Vibrio harveyi. African Journal of Microbiology Research 4, 1794-1800.

Raisanen, L., Draing, C., Pfitzenmaier, M., Schubert, K., Jaakonsaari, T., Von Aulock, S., Hartung, T. and Alatossava, T. (2007). Molecular interactin between lipoteichoic acids and Lactobacillus delbrueckii phages depends on D-alanyl and $\alpha$ glucose substitution of poly (glycerophosphate) backbones. Journal of Bacteriology 189, 41354140.

Roncero, C., Darzins, A. and Casadaban, M. J. (1990). Pseudomonas aeruginosa transposable bacteriophages D3112 and B3 require pili and surface growth for adsorption. Journal of Bacteriology 172, 1899-1904.

Schmerer, M., Molineux, I. J. and Bull, J. J. (2014). Synergy as a rationale for phage therapy sing phage cocktails. PeerJ 2, 1-16.

Sudershan, R. V., Kumar, R. N., Kulkarni, B., Kashinath, L., Bhaskar. V. and Polasa, K. (2014). E. coli pathoypes and their antibiotic resistance in young children with diarrhea in Hyderabad, India. International Journal of Current Microbiology and Applied Sciences 3, 647-654.

Suthereland, I. W., Hughes, K. A., Skillman, L. C. and Tait, K. (2004). The interaction of phage and biofilms. FEMS Microbiology Letters 232, 1-6.

Tortora, G. J., Funke, B. R. and Case, C. L. (2006). Microbiology: An Introduction. Benjamin Cummings, New York. pp. 810.

Zhang, Q., Sahin, O., McDermott, P. F. and Payot, S. (2006). Fitness of antimicrobial-resistant Campylobacter and Salmonella. Microbes and Infection 8, 1972-1978. 